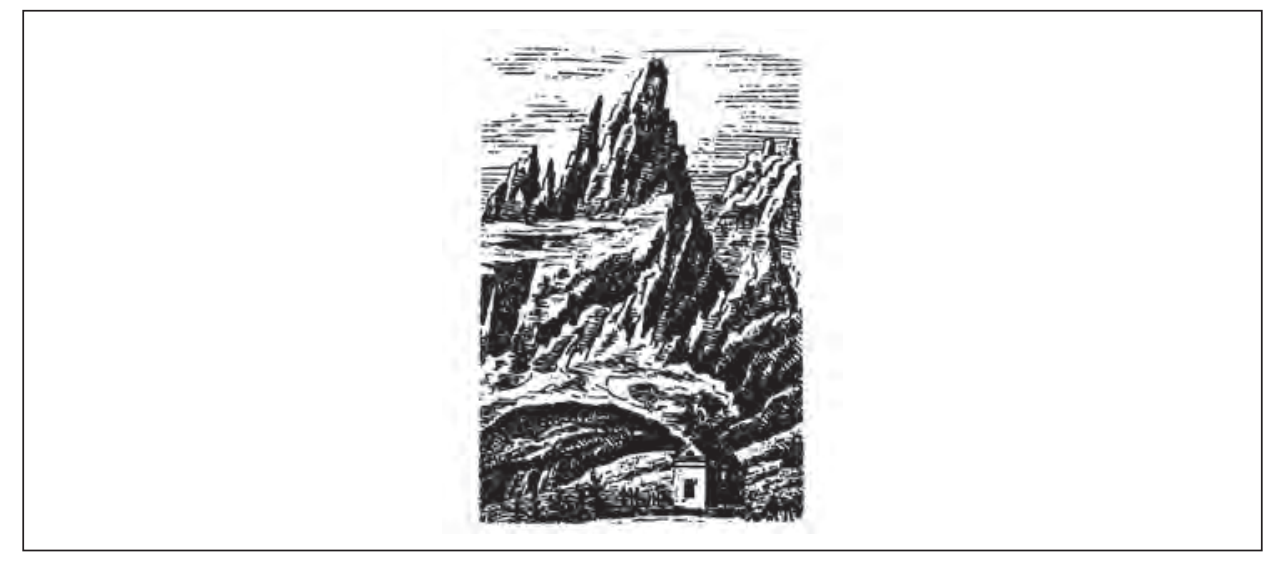

\author{
Anna Pigoń \\ ORCID: 0000-0002-3098-1888 \\ Uniwersytet Wrocławski \\ anna.pigon@wp.eu
}

https://doi.org/10.19195/2084-4107.13.18

\title{
Obraz gór w kobiecych narracjach o Tatrach do 1939 roku
}

Słowa-klucze: feminizm, góralka, idealizacja, kobieta, Tatry

Keywords: feminism, highlander, idealisation, woman, Tatras

\section{The image of the mountains in women's narratives featuring the Tatras until 1939}

\section{Summary}

Women's narratives from before 1939 constitute a small part of the entire literature dealing with the Tatras. Many of them have been forgotten owing to their limited artistic value as well as limited contribution to the development of literary culture in the Podhale region. An important and often dominant feature of women's narratives concerning the Tatras is idealisation of the mountains.

The article focuses on the idealistic image of the Tatras created by female writers before 1939 . The basic research method adopted by the author is geocriticism, which provides for the creation of a typology of female writers based on their links to geographic space. In the case of Tatra narratives, the female writers can be divided into highland women (indigenous inhabitants), guests (women staying in the Podhale region temporarily) and residents (non-indigenous inhabitants). 
Each of these groups sees the Tatras slightly differently and idealises them in a slightly different manner. The way female writers see the mountains is sometimes uniquely escapist (which is associated with the treatment of Podhale as a land of childhood years and concerns mainly the indigenous inhabitants of the region); is connected with the category of stereotype, which stems from a common, superficial perception of the mountains (this, in turn, is the domain of guest writers); thirdly — idealisation is a form of a demand.

The author of the article discusses the various groups of female writers and the idealising devices they use in their works. The works analysed by the author include those by Gea Dobrzańska, Aniela Gut-Stapińska, Zofia Urbanowska and Gabriela Zapolska.

Badania dotyczące relacji podmiotu obserwującego z przedmiotem obserwowanym, czyli w tym wypadku kobiety narratorki z górami, ich wzajemnego oddziaływania na siebie i sposobu percepcji przedmiotu powinny brać pod uwagę przynależność środowiskową autorek tych narracji. Odpowiednich narzędzi do analizy tego typu zależności dostarcza geokrytyka, która proponuje stworzenie typologii pisarek ze względu na sposób ich powiązania z przestrzenią. Jak pisze Elżbieta Rybicka, referując ustalenia Bertranda Westphala:

Endogeniczny punkt widzenia charakteryzuje pozycję autochtona $\mathrm{w}$ danej przestrzeni, egzogeniczny należy do podróżnika, jest więc domeną egzotyzmu, allogeniczny sytuuje się natomiast pomiędzy nimi ${ }^{1}$.

Analiza kobiecych narracji o Tatrach wykorzystująca tę metodę mogłaby zatem uwzględniać podział autorek na góralki (rdzenne mieszkanki), gościnie (przebywające na tym obszarze chwilowo) i rezydentki (nierdzenne mieszkanki, mieszkanki z wyboru). Taka typologia wydaje się optymalna do pełnego przedstawienia różnorodności owych narracji, a także multifokalizacji — relacji z przestrzenią (czyli relacji między podmiotem obserwującym a przedmiotem obserwowanym). To właśnie interakcja między narratorem a przestrzenią jest najważniejszym elementem tej metody, która służy określeniu stosunku narratora do tego, co opisuje.

Kobiece narracje do 1939 roku są niewielką częścią całej literatury o Tatrach. Jacek Kolbuszewski w monografii Tatry w literaturze polskiej wymienia nieco ponad pięćdziesiąt nazwisk autorek ${ }^{2}$ (autorów zaś kilkakrotnie więcej), z czego zdecydowana większość uległa zapomnieniu z powodu niskiej wartości artystycznej dzieł o Tatrach i Podhalu autorstwa kobiet oraz ich niewielkiego wkładu w rozwój literackiej kultury na Podhalu³ ${ }^{3}$ Przyczyny takiej pozycji literatury o Tatrach autorstwa kobiet są $\mathrm{w}$ jakimś stopniu wynikiem szerszych zjawisk społecznych związanych z powolnym procesem ich emancypacji nie tylko na Podhalu, lecz także poza nim.

${ }^{1}$ E. Rybicka, Geopoetyka. Przestrzeń i miejsce we wspótczesnych teoriach i praktykach literackich, Kraków 2014, s. 71.

2 J. Kolbuszewski, Tatry w literaturze polskiej 1805-1939, Kraków 1982.

3 Oczywiście przyczyn takiego stanu rzeczy może być więcej i mogą one wiązać się z percepcją dziewiętnasto- i dwudziestowiecznej twórczości kobiet w ogóle, jest to jednak zagadnienie odległe od tematu niniejszego artykułu. 
Co jednak dosyć charakterystyczne i być może związane z wtórnością utworów autorstwa kobiet o tematyce tatrzańskiej oraz ich stosunkowo małą liczbą w porównaniu z literaturą pisaną przez mężczyzn, idealizacja Tatr w twórczości kobiet wydaje się istotną i nierzadko główną cechą ich narracji. Być może jest to skutek w pewnym sensie selektywnego oddziaływania narzuconej przez literaturę wysokoartystyczną konwencji oraz opóźnionego w stosunku do środowisk męskich eksplorowania Tatr. Do pewnego momentu aktywność kobiet $\mathrm{w}$ górach była bowiem sporadyczna kobiece taternictwo na przykład długo musiało się zmagać z niechęcią mężczyzn oraz trudnościami natury fizycznej i społeczno-kulturowej.

Kobiety odegrały również o wiele mniejszą rolę w formowaniu kulturowego mitu Podhala, zwłaszcza na samym początku jego rozwoju. Legendowe postaci Tatr i Zakopanego to przede wszystkim mężczyźni: Tytus Chałubiński, Andrzej Chramiec, Jan Krzeptowski Sabała czy ks. Józef Stolarczyk. Kobiety nie pojawiły się zatem w gronie twórców i animatorów życia społecznego wyposażających tę przestrzeń w nowe znaczenia, kreujących jej warstwę symboliczną, choć w twórczości literackiej często się do niej odwoływały.

W utworach autorstwa kobiet przestrzeń górska bywała idealizowana co najmniej na trzy sposoby: po pierwsze, jej widzenie mogło być swoiście eskapistyczne (miało to związek z pojmowaniem Podhala jako kraju lat dziecinnych, co dotyczyło głównie rdzennych mieszkanek regionu); po drugie, wiązało się z kategorią stereotypu, co wynikało z potocznego, powierzchownego patrzenia na góry; po trzecie wreszcie, idealizacja była formą postulatu — w tym wypadku zgodnie z zasadami arystotelesowskimi pomijanie pewnych aspektów miało na celu przedstawienie wzorca, do którego należy dążyć.

Wszystkie autorki będące przedmiotem niniejszych rozważań są związane z górami i Podhalem, przy czym ich relacje z przestrzenią tatrzańsko-podhalańską są zróżnicowane. Nie w każdym przypadku możliwe jest ustalenie, w jakim stopniu dana autorka była związana z Podhalem: zaangażowana w życie towarzyskie pod Tatrami, taternictwo czy dziedzictwo kulturowe regionu. Część z nich bowiem to pisarki zapomniane - po ich obecności w Zakopanem i okolicach nie ma dziś śladu.

Idealizowanie kraju lat dziecinnych to zabieg dosyć częsty w twórczości autorek urodzonych na Podhalu. Zjawisko to można rozpatrywać w kategoriach swoistego eskapizmu. Jak się wydaje, szczególnego wymiaru nabrało w okresie znaczących przemian na terenie Tatr i Podhala. Narastająca komercjalizacja, wynikające z urbanizacji tych terenów zmiany krajobrazu oraz egalitaryzacja samych Tatr prowadzą do ucieczki w stronę mitycznego ,złotego wieku” Tatr dziewiczych, czasu prymatu natury nad kulturą. Wiąże się to z położeniem nacisku na konkretne grupy społeczne przedstawiane w twórczości kobiet pochodzących z Podhala. Najczęściej są to bohaterowie wywodzący się z regionu: górale wraz z ich tradycją, kulturą, zwyczajami, ewentualnie inni stali mieszkańcy pochodzący z okolic położonych w cieniu Tatr. Zdarza się, że to właśnie rezydenci w większym stopniu idealizują Tatry i pogórze. Wprawdzie nie urodzili się na Podhalu, ale wybrali je 
jako miejsce do życia; oznaczałoby to, że kategoria wyboru w pewnym stopniu warunkuje idealizację i ma wpływ na tendencje do mitologizacji przestrzeni.

Wyidealizowany obraz Tatr i ludowej kultury mieszkańców Podhala pojawia się na przykład w twórczości Anieli Gut-Stapińskiej (1898-1954) — góralki z Poronina, szczególnie aktywnej w okresie międzywojennym, lecz także powojennym. Zarówno w prozie, jak i poezji zwraca ona szczególną uwagę na miejscową społeczność, jej wierzenia i lokalną kulturę ludową. Kreując krajobrazy górskie, manifestuje emocjonalny z nimi związek i często podkreśla, że jest to jej ziemia ojczysta. Poemat Marynka z Poronina, zawierający wiele elementów autobiograficznych, traktuje między innymi o Tatrach widzianych jako miejsce idylliczne:

O góry, góry! W czar mocy zaklęte!

Szemrzą fale Dunajca o was pieśni święte,

Nie chcą was odpłynąć i z wami się rozstać,

Chciałyby znieruchomieć i na wieki ostać 4 .

Maria Jazowska-Gumulska wskazuje jednak na niesamodzielność twórczości Gut-Stapińskiej, przynajmniej w zakresie formalnym. Według niej autorka w opisach przestrzeni zdradza bowiem wyraźne inspiracje dorobkiem Adama Mickiewicza, Juliusza Słowackiego czy Stanisława Wyspiańskiego5. Mimo owej wtórności można przyjąć, że prezentowany przez nią eskapizm nie jest afektowany, co wynika między innymi z jej podstawowego wykształcenia i zakorzenienia w tradycjach Podhala. Gut-Stapińska odnosi się tylko do tego, co jest jej dobrze znane i co stanowi jej niematerialne dziedzictwo.

Społeczność napływową, ale mocno wtopioną w kulturę regionu, portretuje z kolei - w jak dotąd niewydanej powieści Idzie lawina! — Jadwiga Roguska-Cybulska (1887-1971). Co ciekawe, również ona spogląda na Tatry i Podhale przez pryzmat konwencji idealizującej „kraj lat dziecinnych”. Wyraźnie nobilituje krajobrazy wysokogórskie, zestawiając je z nizinami. Może to uzasadniać fakt, że pisarka była rezydentką Zakopanego — mieszkała tam na stałe od 1927 do swojej śmierci w 1971 roku. Uprawiała taternictwo oraz narciarstwo (jako jedna z pierwszych kobiet), była członkinią Sekcji Turystycznej Towarzystwa Tatrzańskiego ${ }^{6}$ — świadczy to o dużym zaangażowaniu Roguskiej-Cybulskiej w przestrzeń, którą wybrała do życia. Zaangażowanie to odbija się w jej twórczości, a dobrym tego przykładem jest właśnie Idzie lawina!

W powieści waloryzowana przestrzeń górska staje się tłem wielu wydarzeń, ale jest również medium pozwalającym na oderwanie młodych bohaterów od zakopiańskich problemów i przeniesienie ich w wymiar arkadyjski. $\mathrm{W}$ otoczeniu gór

${ }^{4}$ Cyt. za: M. Jazowska-Gumulska, Gęśle z Jawora. O regionalnych pisarzach Podhala w dwudziestoleciu międzywojennym, Zakopane 1990, s. 139.

5 Ibidem.

${ }^{6}$ Roguska-Cybulska Jadwiga, [hasło w:] Z. Radwańska-Paryska, W.H. Paryski, Encyklopedia tatrzańska, Warszawa 1973, s. 435-436. 
realizują się bowiem miłosne scenariusze, o czym świadczy fragment opisujący zbliżenie dwojga zakochanych w sobie uczniów zakopiańskiego gimnazjum:

Może właśnie z tych wszystkich przyczyn przeżycia miłosne w otoczeniu dzikich gór miały dla nich wagę złota, gdy w skupiskach ludzkich, zmieniane na drobne, były rozrzucane garściami jak bezużyteczne odpadki. Może dlatego pocałunek dwojga zakochanych w tych niecodziennych warunkach posiadał dla ich wartość klejnotu, gdy tam, na nizinach, stawał się zdawkową monetą w ciągłym obiegu?

Góry stają się tu także scenografią fantazji na temat śmierci, które snuje młodociana bohaterka Ilka, przekonana, że jej ukochany interesuje się inną dziewczyną:

— Jeżeli oni się kochają, to ja nie mam, po co żyć.

I zaczęła myślą przebiegać wszystkie znane jej pobliskie szczyty tatrzańskie... Szukała w nich najbardziej przepaścistej zerwy skalnej... z której skok przeciąłby jej żywot bezcelowy ${ }^{8}$.

Z kolei w twórczości autorek odwiedzających Podhale w celach turystycznych i wypoczynkowych, często kierujących się raczej modą na Tatry niż autentyczną ich ciekawością i chęcią poznania, można zaobserwować tendencje do kreowania uproszczonego, stereotypowo wyidealizowanego obrazu przestrzeni górskiej. Wspomniana wcześniej szablonowość może w jakimś stopniu wynikać z powierzchownego poznania modnych Tatr i Podhala (w tym wypadku autorki sięgają po paradygmaty ustanowione przez swoich poprzedników — zazwyczaj mężczyzn). Nawet jeśli krajobraz górski wyzwala emocje, to jednak ograniczony czasowo kontakt z tą przestrzenią i brak doświadczenia w obcowaniu z nią, a co za tym idzie — brak jej dogłębnego zrozumienia, może poniekąd wpływać na rezygnację z oryginalności na rzecz wpisania się w obowiązującą tradycję literacką.

Dobrze ilustruje to fragment wspomnienia Marty Hubickiej (1877-1936) Moja pierwsza wycieczka w Tatry, opublikowanego w 1931 roku na łamach „Ziemi”. Autorka była nauczycielką i literatką urodzoną w Nasielsku. Zajmowała się głównie Kielecczyzną; jej prace — zarówno druki zwarte, jak i artykuły w czasopismach - dotyczą właśnie tych terenów, a także wywodzącego się stamtąd Stefana Żeromskiego. Hubicka nie podaje daty swojego pierwszego zetknięcia z Tatrami, jednak ze wstępnych opisów można wywnioskować, że akcja króciutkiego utworu rozgrywa się na początku XX wieku. Literatka wspomina bowiem między innymi o wykładach Stanisława Brzozowskiego, które ten wygłaszał na Podhalu, a także o zamkniętym pokazie Tkaczy Gerharta Hauptmanna9

7 J. Roguska-Cybulska, Idzie lawina!, [mps], 1938, Archiwum Muzeum Tatrzańskiego, AR/NO/1124/1-2, s. 409.

8 Ibidem.

9 Pokaz odbył się w 1904 roku; por. K. Estreicher, Środowisko artystyczne Zakopanego w okresie Młodej Polski (1900-1914), [w:] Sztuka około 1900. Materiaty Sesji Stowarzyszenia Historyków Sztuki, Warszawa 1969, s. 131. 
Bohaterka wspomnienia, początkowo nastawiona sceptycznie, z chwilą zetknięcia się z wysokimi górami poddaje się ich działaniu, przeżywając nawet coś na kształt swoistego katharsis; po osiągnięciu celu wędrówki deklamuje wiersz:

Sama jestem — wokoło olbrzymy z granitu.

Dumne igły krzesanic rosną wprost ze śniegu:

dziwny ogród, zamknięty okolem błękitu, trochę z tego, a trochę - już z tamtego brzegu ${ }^{10}$.

Ten prosty konwencjonalny wiersz świadczy o wtórności środków wyrazu, po jakie sięga autorka. Służą one hiperbolizacji oglądanego pejzażu, współtworząc typową dla tego typu ujęć aurę mistyczną. W kontekście wcześniejszych opisów trudów wędrówki i obojętności bohaterki na otaczający ją krajobraz mamy tu do czynienia z zakorzenionym $\mathrm{w}$ tradycji literackiej obrazem przemiany, którą powoduje natura. Bardzo podobny zabieg zastosował w jednym ze swoich felietonów Kornel Makuszyński. Narrator VIII listu z Zakopanego, podstępem wyprowadzony na Granaty przez Tadeusza Boya-Żeleńskiego oraz Witkacego, dotychczas pełen dystansu do siebie i świata, ironiczny i złośliwy, po osiągnięciu celu wędrówki stwierdza: „A kiedy się wpółmartwy znalazłem na jakimś szczycie, skąd się roztoczył widok na niebo i chyba na całą ziemię, niebo wstąpiło we mnie, jasność, rozkosz, radość i wesele. Jestem wniebowzięty" "In. Znów zatem — o ile hipoteza o inspiracji Makuszyńskim jest prawdziwa - mamy do czynienia z podążaniem za męskim wzorcem przy opisie emocji towarzyszących zdobyciu szczytu.

Nawet w utworach, w których przestrzeń górska nie odgrywa żadnej roli, zostaje ona odmalowana w sposób specyficznie wyidealizowany. Pokazuje to wyimek z powieści Gabrieli Zapolskiej (1857-1921) Sezonowa miłość, w której choć w planie fabularnym Tatry praktycznie nie istnieją, to jako element tła jawią się jako odrealnione, mistyczne, wręcz zsakralizowane i wyidealizowane:

Od Tatr, od hal, od wianków kosodrzewiny, na które spływał welon śniegów, niosło przedziwną wonią świeżej żywicy i czystego Ducha. Dobro tam panowało. [...] Lecz o warstwę nędzy, niby zdobytej doskonałością życiowych, ludzkich, mrówczych zabiegów w celu ulepszenia bytu i umożliwienia wygodnej podściółki duszy i ciała, obijały się często na próżno owe świeże, wonne i czyste wiewy nad szmaragdem lasów wnoszącego się archanielskiego skrzydła ${ }^{12}$.

Nie sposób nie powiązać tutaj kategorii idealizacji ze stereotypowym sposobem ukazywania obrazu Tatr pojawiającym się również w wielu innych fragmentach powieści.

${ }^{10}$ M. Hubicka, Moja pierwsza wycieczka w Tatry, „Ziemia” 16, 1931, nr 23-24, s. 376.

${ }^{11}$ K. Makuszyński, List z Zakopanego [fragment], [w:] Tatry i górale w literaturze polskiej. Antologia, oprac. J. Kolbuszewski, Wrocław 1992, s. 532.

12 G. Zapolska, Sezonowa miłość, Warszawa 2012, s. 39. 
Owa stereotypowość wynika z braku wyraźnych związków autorki Moralności pani Dulskiej z Tatrami. Zapolska spędziła w Tatrach letnie wakacje 1885 roku ${ }^{13}$, blisko zaś dwadzieścia lat później — od kwietnia 1903 do stycznia 1904 roku — przebywała w Zakładzie Hydropatycznym doktora Andrzeja Chramca ${ }^{14}$. W obu wypadkach wydaje się, że nie zaangażowała się w specyfikę podhalańskiej codzienności, a Sezonowa miłość — pokłosie pobytu z lat 1903-1904 — zdaje się jedynie próbą wpisania się w obowiązującą u progu XX wieku „modę na Tatry”.

Autorki niezwiązane bliżej z Podhalem, postrzegające je przede wszystkim pośrednio, przez pryzmat tego, co zostało już o nim powiedziane, z reguły zdają się od-twarzać górską przestrzeń, a nie stwarzać ją na nowo. Odwołują się tu często do klasycznej opozycji idealnej góry i niedoskonałego dołu. Tak dzieje się u wspomnianej Zapolskiej, w której twórczości krajobraz górski i przyroda Tatr to przede wszystkim tło i usprawiedliwienie pewnych zachowań i czynów bohaterów.

Idealizacja polegająca na operowaniu prostymi wzorcami, powiązana ze stereotypizacją, właściwa jest przede wszystkim autorkom-gościniom, i to gościniom chwilowym, dla których górska przestrzeń jest narzędziem, materiałem pomocniczym w ukazywaniu tego, na czym zależy im najbardziej. Mogą to być uczucia romantyczne - poza wspomnianą powieścią Zapolskiej tego typu tendencja pojawia się też w prozie Gei Dobrzańskiej — autorki, co do której możemy jedynie domniemywać, że odwiedziła Zakopane jedynie turystycznie, nie osiedlając się tam na dłużej (jej zbiór nowel został wydany w Poznaniu i w tamtejszej prasie ukazała się jego recenzja, a także reklamy zachęcające do kupna tomu ${ }^{15}$ ). W jednej z nowel autorstwa Dobrzańskiej — zatytułowanej Kartki znalezione na Antałówce - uczucia targające bohaterką mają wpływ na idealizujące postrzeganie przez nią otaczającej przestrzeni:

Po raz to pierwszy wówczas Zakopane wydało mi się cudowne, a góry jak bajeczny sen o jakichś zaklętych, lodowcowych olbrzymach. Ale też Bolesław uczył mię patrzeć na białe, śnieżne Tatry okiem malarza ${ }^{16}$.

Z kolei w twórczości poetyckiej autorek piszących o Tatrach zdarza się, że obraz tych gór powoduje powstanie uczuć patriotycznych. Widoczne jest to w poezji Marii Konopnickiej (1842-1910), dla której Tatry są symbolem polskości. Po raz pierwszy Konopnicka znalazła się w Zakopanem w kwietniu 1890 roku ${ }^{17}$, podczas pobytu w nieodległej od Krakowa Suchej udała się na kilka dni na Podhale. Pod przewodnictwem Macieja Sieczki zwiedziła Dolinę Kościeliską, gdzie — jak

13 J. Czachowska, Gabriela Zapolska. Monografia bio-bibliograficzna, Kraków 1966, s. 44.

14 Ibidem, s. 302.

15 Reklamy ukazywały się na łamach „Gońca Wielkopolskiego” od 1915 do 1923 roku, recenzję zaś, a właściwie pochlebną wzmiankę o zbiorze, opublikowano w „Kurierze Poznańskim” w 1916 roku.

16 G. Dobrzańska, Kartki znalezione na Antałówce, [w:] eadem, Z zakopańskich tchnień. Nowele, Poznań 1914, s. 18.

17 T. Czapczyński, Tułacze lata Marii Konopnickiej. Przyczynki do biografii, Wrocław 1957, s. 11. 
twierdziła — wyczuła ducha Seweryna Goszczyńskiego; duże wrażenie wywarło na niej także poznanie Sabały.

Druga wizyta w Tatrach doszła do skutku dopiero w 1905 roku. Konopnicka wraz z towarzyszącą jej Marią Dulębianką zwiedziły wówczas najpopularniejsze dziewiętnastowieczne miejsca turystyczne: Dolinę Kościeliską ze Stawem Smreczyńskim oraz Morskie Oko. Z uwagi na jej wiek (63 lata) nie były to dalekie i wymagające wyprawy. Tak Konopnicka podsumowała wycieczkę: ,,pełno znajomych, drożyzna, karota na cele dobroczynne, wyzysk ze strony górali i cudowne góry - oto Zak[opane]"18.

Te na poły „nizinne”, sprzężone raczej z kulturą aniżeli tatrzańską naturą fascynacje znalazły odzwierciedlenie w twórczości poetki, między innymi w wierszu U Pięciu Stawów, w którym Konopnicka wpisuje pejzaż tatrzański w szerszy, ojczyźniano-patriotyczny kontekst; pisze bowiem o dolinie, że tam: „kują duchy koronę polską i cała już gotowa, tylko brakuje jeszcze jednego drogiego kamienia, którego jeszcze nie ma, ale się znajdzie"19.

Innym przykładem zespolenia obrazu Tatr z problematyką narodową jest twórczość Marii Kaczkowskiej. Bohater powiastki Śpiacy rycerz w Tatrach - Jontek - powraca w ojczyste (tatrzańskie) strony, gdy lecąc na obłoku nad Doliną Kościeliską, słyszy rozmowę o zbliżającej się wojnie; zatem to miłość do ojczyzny jest tu źródłem nostalgicznego wspomnienia o kraju lat dziecinnych ${ }^{20}$. Tu również mamy do czynienia z prostą opozycją gór jako przestrzeni przyjaznej, sprzyjającej rozwojowi tożsamości ukształtowanej na podstawie związku emocjonalnego z rodzinną ziemią i odległej, obcej krainy, gdzie traci się pamięć o własnym pochodzeniu i społecznych powinnościach.

Zabiegi idealizujące bohaterów lub elementy świata przedstawionego związane są także z dydaktyczną funkcją literatury, zwłaszcza w zakresie wskazywania wzorców moralnych. Nie dziwi więc obecność takich zabiegów w literaturze dziecięco-młodzieżowej, choć zastanawiać może — w wypadku utworów o Tatrach - przesunięcie punktu ciężkości z bohaterów na świat przedstawiony: obrazy natury (sprzężonej z kulturą), kreacje pejzażu górskiego z wtopioną w tło społecznością góralską (występującą tu zazwyczaj nie w charakterze czynnych bohaterów, lecz tła wydarzeń, dopełniającego koloryt lokalny) czy historię.

W gronie autorek piszących o Tatrach najwięcej z nich uprawia właśnie literaturę dziecięco-młodzieżową (w tym kontekście Pola Kuleczka kobiet pisarek wymienia około sześćdziesięciu) ${ }^{21}$. Liczne ich utwory, których akcja rozgrywa się w Tatrach i na Podhalu, pretendują do miana swoistych kompendiów wiedzy o górach i sposobach ich zamieszkiwania; kompendia te oprócz funkcji rozrywkowej mają też uczyć poprzez przekazywanie istotnych informacji o przyrodzie
18 Ibidem, s. 47.
19 M. Konopnicka, U Pięciu Stawów, [w:] Tatry i górale..., s. 232.
${ }^{20}$ M. Kaczkowska, Śpiacy rycerz w Tatrach. Baśń, Lublin 1918.
${ }^{21}$ P. Kuleczka, Tatry w literaturze polskiej dla dzieci i młodzieży do roku 1939, Zielona Góra 1994. 
oraz kulturze regionu. Taki charakter mają między innymi międzywojenne powieści: Z włóczęgi wakacyjnej Zofii Lepeckiej, Tajemnica Tatr Jadwigi Roguskiej-Cybulskiej czy Róża bez kolców Zofii Urbanowskiej (1849-1939). Stopień ich związania z Podhalem był zróżnicowany, bo o ile Roguska-Cybulska była — jak wspomniano - stałą mieszkanką, o tyle Urbanowska jedynie odwiedzała Zakopane, choć czyniła to regularnie od 1890 roku. Wydana po raz pierwszy w 1903 roku Róża bez kolców była zatem pokłosiem wieloletnich cyklicznych podróży, podczas których pisarka poznawała specyfikę Tatr i Podhala ${ }^{22}$. Nieznane są natomiast związki z Podhalem Lepeckiej; można jedynie domniemywać na podstawie lektury jej utworu, że Zakopane mogło się pojawić na trasie jej turystycznych eksploracji, było jednak prawdopodobnie zaledwie przystankiem w podróży, jako że bohaterowie $Z$ włóczęgi wakacyjnej odwiedzają zarówno Tatry, jak i morze oraz jezioro (co zdradza zresztą już podtytuł dzieła).

W wymienionych powieściach dla młodzieży w dość specyficzny sposób krzyżują się procesy odkrywania przestrzeni — zarówno przez bohatera, jak i czytelnika. Jest to od samego początku przestrzeń nierozerwalnie sprzężona $\mathrm{z}$ tradycją literacką i kulturową, która jest jedynie zapleczem wiedzowym bohaterów i którą jest karmiony czytelnik. Jak pisze Pola Kuleczka, w tego typu utworach „zarysowała się [...] dobrze znana przynajmniej od czasów Róży bez kolców Zofii Urbanowskiej tendencja do łączenia schematu przygodowego z encyklopedyczno-informacyjną warstwą dzieła" 23 . Wskazują na to szczegółowe informacje topograficzne bądź etnograficzne pojawiające się w dialogach prowadzonych przez bohaterów lub w przypisach, jak na przykład u Lepeckiej: „, to Czarny Staw, zawieszony o 191 metrów nad jeziorem"24 czy Urbanowskiej:

[Sabała] jest to stary góral, mający już około osiemdziesięciu lat, a chodzący po szczytach jakby miał dopiero dwadzieścia, poeta i zarazem filozof, postać bardzo oryginalna. Całym jego majątkiem są gęśliki, czyli skrzypki, które nosi zaszyte w rękawie swej cuchy ${ }^{25}$.

Dość symptomatyczny jest tu zabieg Urbanowskiej polegający na wzbogacaniu każdego rozdziału w motto. Zazwyczaj jest to cytat pochodzący z utworów popularnych poetów i poetek Podhala: głównie Deotymy, ale też Adama Asnyka czy Wincentego Pola. Służy to nie tylko celom edukacyjnym i popularyzatorskim, lecz także — podobnie jak u omawianej w dalszej części artykułu Zofii Lepeckiej — zabieg ten sprawia, że powieść pośrednio nawiązuje do dziewiętnastowiecznego mitu ,złotego okresu” Tatr.

Urbanowska idealizuje nie tylko górską przestrzeń, ale i ludzi z nią związanych. Pokazuje to dialog bohaterów doceniających góralską gwarę:

${ }^{22}$ Zofia Urbanowska, [hasło w:] Z. Radwańska-Paryska, W. H. Paryski, op. cit., s. 583.

23 Ibidem, s. 221.

${ }^{24}$ Z. Lepecka, Z włóczęgi wakacyjnej. Nad morzem, w górach, nad jeziorem, Warszawa 1928, s. 82 .

25 Z. Urbanowska, Róża bez kolców, Warszawa 1958, s. 139. 
— I w mowie górali też pan nie znajdujesz nowych a malowniczych wyrażeń? Przed chwilą mówiła gaździna, że jej ,zapaska poszła na dziady”. [...] ja się wsłuchuję w ich język, chciwie łowiąc każdą nowość; u nas służąca powiedziałaby, że podarła fartuch na nic. A co to jest fartuch? To żywy zabytek germański. O ileż od niego piękniejsza ,zapaska”!26

Nobilitacja języka górali wynika w tym wypadku z tego, że staje się on nośnikiem polskości. Pozytywna ocena góralszczyzny wychodzi zatem poza obręb regionalny, nabierając szerszego wymiaru patriotycznego.

W utworach Lepeckiej, Roguskiej-Cybulskiej i Urbanowskiej góry są dla bohaterów spełnieniem marzeń, przestrzenią odkrywania, a nawet scenerią przejścia, w tym wypadku dorastania. Równie ważny jak bohater — jeśli nie ważniejszy — jest młody czytelnik, który otrzymuje kluczowe i zróżnicowane informacje dotyczące historii Tatr i Zakopanego, topografii, folkloru czy tradycji literackiej w kontekście Podhala. Nie dziwi więc, że Tatry w tego typu utworach jawią się jako idylla, kraina pozbawiona wad, w której wszelkie trudności można łatwo pokonać. Co jednak istotne, w świetle powieściowych dyskursów jest to kraina, o którą należy dbać i którą należy szanować.

Aby wypracować w czytelniku poczucie wyjątkowości przestrzeni, jaką odkrywa on za pośrednictwem narratora i bohaterów, trzeba mu nieustannie przypominać, jakim ciężarem tradycji owa przestrzeń tatrzańska jest obarczona. Zofia Lepecka opisuje zatem Dolinę Kościeliską w sposób swoiście wartościujący, wydobywając nie tylko jej wyjątkowe walory estetyczne, lecz także kulturowe:

Więc ujmę ją taką, jaką widywali nasi poeci: Adam Asnyk, Wincenty Pol, Seweryn Goszczyński. Dwa szeregi skał, na których załamują się odblaski nocy, przystrajając góry w fantastyczne szaty. U ich stóp z jednej strony gra wieczorną kołysankę srebrny pas strumienia; z drugiej, ginie w mroku ślad białej ścieżki, wijącej się wśród soczystych traw. Wysoko, jak biała lampa, błyszczy księżyc. W jednym miejscu, ze skalistego łańcucha, wyrywa się na czoło odłam granitu, do złudzenia przypominający kształtem swym sowę. Jej wielki, kamienny dziób, odcina się na tle nieba, jak władny symbol króla nocy ${ }^{27}$.

Autorka świadomie nawiązuje tu do tradycji literackiej i nadaje znaczenia przestrzeni górskiej (tatrzańskiej) w ślad za konwencją ukształtowaną przez znanych polskich poetów romantycznych i postromantycznych: Asnyka, Goszczyńskiego, Pola. Z kolei paleta barw, którą operuje Lepecka w opisie Doliny Kościeliskiej, wskazuje na proweniencje młodopolskie, między innymi wpływy poezji Jana Kasprowicza i Kazimierza Przerwy-Tetmajera.

Podobnie skonwencjonalizowana paleta kolorów dominuje także w opisie Morskiego Oka w powieści Tajemnica Tatr autorstwa Jadwigi Roguskiej-Cybulskiej:

${ }^{26}$ Ibidem, s. 21.

27 Z. Lepecka, op. cit., s. 62. 
Kilka pasm skalnych o fantastycznym rysunku wyłaniało się jedno spoza drugiego, a każde o innej barwie, każde w odrębnym oświetleniu. Najdalsze złociły się jeszcze resztkami purpurowej zorzy zachodniej; następne kąpały się w seledynowych refleksach zmierzchu; wreszcie najbliższe tonęly w fioletowych mrokach ${ }^{28}$.

Autorka nie pozostaje także obojętna wobec regionalnych cech zakopiańskiej architektury, szczególne walory estetyczne dostrzega w stylu zakopiańskim, na co wskazuje wartościująca opinia wpleciona do powieściowej narracji. Bohaterka Tajemnicy Tatr — pani Wrażewska — ,zamieszkała z synem w jednej z piękniejszych willi w pobliżu świerkowego lasu. Była ona w stylu zakopiańskim, czyli witkiewiczowskim"29. Powieść ta, ukończona w 1930 roku, a zatem w okresie rozbudowy Zakopanego i poszukiwania nowych urbanistycznych rozwiązań przestrzennych, zdaje się postulować konieczność objęcia ochroną i troską tego, co w tym zakresie zostało do tej pory osiągnięte.

Mniej lub bardziej widoczne tendencje do idealizacji przestrzeni górskiej w kobiecych narracjach o Tatrach świadczą o subtelnej specyfice kobiecej optyki, co jednocześnie nie chroni tej twórczości przed wtórnością i nieustannym nawiązywaniem do wyraźnie utrwalonej konwencji artystycznej. Nie umniejsza to jednak znaczenia tej twórczości, gdyż stanowi ona głos odrębny i ważny dla kompletności literackiego obrazu Tatr i Podhala.

\section{Bibliografia}

\section{Teksty}

Dobrzańska G., Z zakopańskich tchnień. Nowele, Poznań 1914.

Hubicka M., Moja pierwsza wycieczka w Tatry, „Ziemia” 16, 1931, nr 23-24.

Kaczkowska M., Śpiacy rycerz w Tatrach. Baśń, Lublin 1918.

Konopnicka M., U Pięciu Stawów, [w:] Tatry i górale w literaturze polskiej. Antologia, oprac. J. Kolbuszewski, Wrocław 1992.

Lepecka Z., Z włóczęgi wakacyjnej. Nad morzem, w górach, nad jeziorem, Warszawa 1928.

Roguska-Cybulska J., Idzie lawina!, [mps], 1938, Archiwum Muzeum Tatrzańskiego, AR/NO/1124/1-2.

Roguska-Cybulska J., Tajemnica Tatr, Warszawa 1957.

Urbanowska Z., Róża bez kolców, Warszawa 1958.

Zapolska G., Sezonowa miłość, Warszawa 2012.

\section{Konteksty}

Czachowska J., Gabriela Zapolska. Monografia bio-bibliograficzna, Kraków 1966.

Czapczyński T., Tułacze lata Marii Konopnickiej. Przyczynki do biografii, Wrocław 1957.

Estreicher K., Środowisko artystyczne Zakopanego w okresie Młodej Polski (1900-1914), [w:] Sztuka około 1900. Materiały Sesji Stowarzyszenia Historyków Sztuki, Warszawa 1969.

28 J. Roguska-Cybulska, Tajemnica Tatr, Warszawa 1957, s. 72.

29 Ibidem, s. 13. 
Jazowska-Gumulska M., Gęśle z Jawora. O regionalnych pisarzach Podhala $w$ dwudziestoleciu międzywojennym, Zakopane 1990.

Kolbuszewski J., Tatry w literaturze polskiej 1805-1939, Kraków 1982.

Kuleczka P., Tatry w literaturze polskiej dla dzieci i młodzieży do roku 1939, Zielona Góra 1994.

Makuszyński K., List z Zakopanego [fragment], [w:] Tatry i górale w literaturze polskiej. Antologia, oprac. J. Kolbuszewski, Wrocław 1992.

Radwańska-Paryska Z., Paryski W.H., Encyklopedia tatrzańska, Warszawa 1973.

Rybicka E., Geopoetyka. Przestrzeń i miejsce we współczesnych teoriach i praktykach literackich, Kraków 2014. 